\title{
Effect of Foliar Application of NAA, GA 3 and Zinc Sulphate on Fruit Drop, Growth and Yield of Ber (Zizyphus mauritiana Lamk.) c.v. Banarasi Karaka
}

\author{
Poornima Devi $^{1 *}$, R.K.S. Gautam ${ }^{1}$, Jyoti Singh ${ }^{1}$, \\ Sunil Kumar Maurya ${ }^{1}$ and Aneeta Chaudhary ${ }^{2}$
}

\author{
${ }^{1}$ Department of Horticulture, C.S.A.U.A.\&T Kanpur (U.P.), India \\ ${ }^{2}$ Department of Horticulture, N.D.U.A.\&T., Faizabad (U.P.), India
}

*Corresponding author

\begin{tabular}{|l|}
\hline Ke y w o r d s \\
Ber, NAA, GA \\
$\mathrm{ZnSO}_{4}$, Fruit \\
\hline Article Info \\
\hline $\begin{array}{l}\text { Accepted: } \\
\text { 12 December } 2018 \\
\text { Available Online: } \\
\text { 10 January } 2019\end{array}$ \\
\hline
\end{tabular}

\section{Introduction}

The Indian Ber (Zizyphus mauritiana Lamk.), which is also known as Chinese date or Chinese fig, belongs to family Rhamnaceae and genus Zizyphus. It is tetraploid in nature with a chromosome number $2 n=4 x=48$. Ber is an ancient fruit tree of India and China. In fact, it was one of the prominent fruits on which sages in ancient India lived during Vedic ages. There is a reference of ber in Yajur Veda, written not later than 1000 B.C. It is said to be indigenous to the area stretching from India to the South Western Asia up to Malaya. It is cultivated widely for its resistance to drought and ability to grow in diversified soil and climatic conditions. Therefore, it is known as "King of Arid Fruits". It requires less care and grows well even in neglected condition and can be successfully grown under the most unfavourable conditions of the soil, water and climate. Ber grows even on the marginal soil and various kinds of wasteland situations such 
as sodic-saline soil, ravines, arid, semi-arid region including plateau region of Bundelkhand and South India. The riped ber fruits have high nutritive value due to which it is conventionally considered as "poor man's fruit". It is richer in protein, phosphorus, calcium and vitamin $\mathrm{c}$ than apple. Various growth regulators and nutrients play an important role in many physiological phenomena like vegetative propagation, induction of seedlessness, increase fruit set, prevention of pre-harvest fruit drop, regulation of flowering, fruit size, thinning of flower and fruits, quality of fruit as well as yield in many tree crops. Auxin inhibits abscission by preventing physiological breakdown of calcium pectate of middle lamella (Bonner, 1950; Van Overbeek, 1959). In ber, fruit set increases and fruit drop decreases by $\mathrm{GA}_{3}$ Bankar and Prasad, 1990, Kale et al., 1999 and Singh et al., 2001). The fruits of ber cultivar 'Banarasi Karaka' are perishable in nature and stored for longer period under normal conditions and can be easily transported to distant places. Long storage life along with high quality ber fruits are needed for enriching human diet and increasing availability for internal as well as external trade. Keeping in view the above facts, the present investigation was undertaken to study the effect of Plant Growth Regulators on growth, flowering, yield and quality of ber cv. 'Banarasi Karaka'.

\section{Materials and Methods}

In the experiment, investigations were conducted on ber cv. "Banarasi Karaka" at Horticulture Garden of Chandra Shekhar Azad University of Agriculture and Technology, Kanpur during 2016-17. The plant material comprised of forty five years old, ten uniform ber trees of cv. "Banarasi Karaka". The orchard soil having ber trees was sandy loam soil having $\mathrm{pH}$ 7.15. All the trees were maintained by uniform cultural practices throughout the period of experiment. In all, there were ten treatments comprising of combination of three levels each of NAA, GA and Zinc Sulphate along with control replicated thrice in Randomised Block Design as $\mathrm{T}_{0}$ Control (water spray), $\mathrm{T}_{1}$ (NAA 10 ppm), $\mathrm{T}_{2}$ (NAA $20 \mathrm{ppm}$ ), T 3 (NAA $30 \mathrm{ppm}$ ), $\mathrm{T}_{4}\left(\mathrm{GA}_{3} 20 \mathrm{ppm}\right), \mathrm{T}_{5}\left(\mathrm{GA}_{3} 30 \mathrm{ppm}\right), \mathrm{T}_{6}\left(\mathrm{GA}_{3}\right.$ $40 \mathrm{ppm}), \mathrm{T}_{7}\left(\mathrm{ZnSO}_{4} 0.2 \%\right), \mathrm{T}_{8}\left(\mathrm{ZnSO}_{4} 0.4 \%\right)$ and $\mathrm{T}_{9}\left(\mathrm{ZnSO}_{4} 0.6 \%\right)$. The trees were sprayed at fruit setting stage during after-noon of clean with fine nozzle sprayer. Care was taken to give uniform spray all over the branches of the plant. Fruits were harvested at mature stage. All the trees were maintained under uniform cultural practices during the period of experimentation.

Observations on fruit set, fruit retention, fruit drop, fruit length, fruit width, fruit volume, fruit weight, pulp weight and yield were recorded at harvest. Data were analyzed statistically.

\section{Results and Discussion}

The application of both PGRs and $\mathrm{ZnSO}_{4}$ significantly improved growth related traits. Experimental findings clearly indicated that the effect of $\mathrm{GA}_{3}$ was better than $\mathrm{ZnSO}_{4}$ and NAA. The fruit set was most enhanced by spray of both 20 and 40 ppm $\mathrm{GA}_{3}\left(\mathrm{~T}_{4}\right.$ and $\left.\mathrm{T}_{6}\right)$ and 0.4 and $0.6 \%$ Zinc ( $\mathrm{T}_{8}$ and $\mathrm{T}_{9}$ ) whereas, fruit retention was increased by $\mathrm{ZnSO}_{4} 0.6 \%$ $\left(\mathrm{T}_{9}\right)$. These results were in close proximity with the findings of Sharma et al., (2009), Ying-yue et al., (2010) and Pandey et al., (2011) in ber respectively. Exogenous application of $\mathrm{GA}_{3}$ inhibits the production of ethylene and higher endogenous levels of gibberellins probably counteract the effects of endogenous ABA which has been ascribed to cause drop in fruits.

Minimum (87.78\%) fruit drop was observed with the spray of $0.6 \% \mathrm{ZnSO}_{4}\left(\mathrm{~T}_{9}\right)$. These 
results are in agreement with those of Ebeed $e t$ al., (2001) in mango and Kumar et al., (2015) in guava. The fruiting attributes in ber was found to be significantly affected due to foliar application of $\mathrm{GA}_{3}$.

Highest fruit length $(4.71 \mathrm{~cm})$, fruit width $(2.76 \mathrm{~cm})$ and fruit volume (15.64) was observed with the treatment $\mathrm{GA}_{3} @ 20 \mathrm{ppm}$ $\left(\mathrm{T}_{4}\right)$, as compared to control and other treatments. The possible reasons for enhancement in fruit size with NAA, $\mathrm{GA}_{3}$ and $\mathrm{ZnSO}_{4}$ might be due to higher synthesis of metabolites and enhanced mobilization of food and minerals from other parts of the plants towards the developing fruits as it is a well-established fact that the fruit acts as extremely active metabolic sink (Table 1 and 2).

Table.1 Effect of NAA, $\mathrm{GA}_{3}$ and $\mathrm{ZnSO}_{4}$ on initial fruit set, fruit retention, fruit drop, length of fruit, width of fruit, fruit volume and fruit weight of ber

\begin{tabular}{|c|c|c|c|c|c|}
\hline Treatments & $\begin{array}{c}\text { Initial } \\
\text { Fruit Set }\end{array}$ & $\begin{array}{c}\text { Fruit Retention } \\
(\%)\end{array}$ & $\begin{array}{c}\text { Fruit } \\
\text { Drop (\%) }\end{array}$ & $\begin{array}{l}\text { Length of } \\
\text { Fruit }(\mathrm{cm})\end{array}$ & $\begin{array}{l}\text { Width of } \\
\text { Fruit }(\mathbf{c m})\end{array}$ \\
\hline $\mathbf{T}_{0}($ Control $)$ & 154 & 6.23 & 93.77 & 3.31 & 2.11 \\
\hline $\mathbf{T}_{1}$ (NAA 10ppm) & 156 & 9.44 & 90.56 & 4.40 & 2.66 \\
\hline $\mathbf{T}_{2}$ (NAA 20ppm) & 158 & 11.69 & 88.31 & 4.12 & 2.39 \\
\hline $\mathbf{T}_{3}$ (NAA 30ppm) & 157 & 12.00 & 88.00 & 3.98 & 2.31 \\
\hline $\mathbf{T}_{4}\left(\mathrm{GA}_{3} 20 \mathrm{ppm}\right)$ & 159 & 8.80 & 91.20 & 4.71 & 2.76 \\
\hline$T_{5}\left(G_{3} 30 p p m\right)$ & 158 & 10.35 & 89.65 & 4.21 & 2.58 \\
\hline$T_{6}\left(G_{3} 40 p p m\right)$ & 159 & 11.66 & 88.34 & 4.06 & 2.61 \\
\hline$T_{7}(\mathrm{Zn} 0.2 \%)$ & 157 & 9.96 & 90.04 & 3.95 & 2.53 \\
\hline $\mathrm{T}_{8}(\operatorname{Zn~} 0.4 \%)$ & 159 & 11.44 & 88.56 & 4.06 & 2.40 \\
\hline$T_{9}(\operatorname{Zn~} 0.6 \%)$ & 159 & 12.22 & 87.78 & 3.98 & 2.37 \\
\hline C.D at 5\% & N.S. & 1.37 & 1.74 & 0.36 & 0.16 \\
\hline
\end{tabular}

Table.2 Effect of NAA, $\mathrm{GA}_{3}$ and $\mathrm{ZnSO}_{4}$ on weight of fruit pulp, yield, specific gravity, total soluble solid, ascorbic acid and total sugar of ber

\begin{tabular}{|c|c|c|c|c|}
\hline Treatments & $\begin{array}{c}\text { Fruit } \\
\text { Volume (cc) }\end{array}$ & $\begin{array}{c}\text { Fruit Weight } \\
\text { (g) }\end{array}$ & $\begin{array}{c}\text { Weight Of } \\
\text { Fruit Pulp (g) }\end{array}$ & Yield (kg/Tree) \\
\hline $\mathbf{T}_{\mathbf{0}}$ (Control) & 10.48 & 10.06 & 8.77 & 20.28 \\
\hline$T_{1}($ NAA 10ppm) & 15.26 & 14.85 & 13.71 & 30.40 \\
\hline$T_{2}($ NAA 20ppm) & 14.12 & 13.46 & 12.83 & 42.52 \\
\hline $\mathbf{T}_{3}$ (NAA 30ppm) & 13.39 & 13.40 & 12.48 & 49.25 \\
\hline $\mathrm{T}_{4}\left(\mathrm{GA}_{3} 20 \mathrm{ppm}\right)$ & 15.64 & 15.68 & 14.64 & 29.95 \\
\hline $\mathbf{T}_{5}\left(\mathrm{GA}_{3} 30 \mathrm{ppm}\right)$ & 14.32 & 14.48 & 13.71 & 35.68 \\
\hline $\mathrm{T}_{6}\left(\mathrm{GA}_{3} 40 \mathrm{ppm}\right)$ & 14.29 & 13.98 & 13.39 & 38.42 \\
\hline$T_{7}(\operatorname{Zn} 0.2 \%)$ & 14.56 & 14.18 & 13.56 & 44.27 \\
\hline$T_{8}(Z n 0.4 \%)$ & 13.57 & 13.88 & 12.88 & 49.29 \\
\hline$T_{9}(Z n 0.6 \%)$ & 13.19 & 13.11 & 12.55 & 52.23 \\
\hline C.D at $5 \%$ & 1.85 & 1.88 & 1.89 & 3.51 \\
\hline
\end{tabular}


It might have also been due to the involvement of these chemicals in cell division, cell expansion, increased volume of intercellular space in the mesocarpic cells and increased absorption of water and mobilization of sugars and minerals in the expanded cells and intercellular space of the mesocarp. The enhancement of fruit size with NAA, $\mathrm{GA}_{3}$ and $\mathrm{ZnSO}_{4}$ might be due to their involvement in hormonal metabolism, increased cell division, elongation and expansion of cells. These results are in accordance with Pandey (1999) and Katiyar et al., (2009) in ber. The increase in fruit weight and pulp weight might be due to the enhanced photosynthetic activity and efficient assimilation of photosynthetic product. Increase in fruit weight may be attributed to the strengthening of middle lamella and consequently cell wall, which later may have increase the free passage of solutes to the fruits. This might have lead to more length and diameter of fruit and also larger weight of individual fruit. There was a positive and significant correlation among the length of fruit with weight of fruit and diameter of fruit with weight of fruit. It was also shown by Wangbin et al., (2008) in ber and Rokaya et al., (2016) in mandarin. The maximum average fruit weight (15.68 $\mathrm{g})$ as well as weight of fruit pulp (14.64 g) were recorded with the application of $\mathrm{GA}_{3} 20 \mathrm{ppm}\left(\mathrm{T}_{4}\right)$. Improvement in pulp content with the use of $\mathrm{GA}_{3}$, NAA and Zinc Sulphate has been observed by Painkara et al., (2012) in mango. This might be due to the growth by cell division and more number of seeds per fruit.

Highest yield per tree $(52.23 \mathrm{~kg})$ with the spray of $\mathrm{T}_{9} \quad\left(\mathrm{ZnSO}_{4} \quad 0.6 \%\right)$ which were significantly superior over the control. These results are in conformity with Singh et al., (2012) in aonla and Omar et al., (2015) in ber.

It is concluded, on the basis of the effect of plant growth regulators and micronutrient which were used as a tool in improving the performance of ber cv. 'Banarasi Karaka' fruits with respect to fruiting and growth attributes in the present investigation. It was concluded that spray of $\mathrm{GA}_{3} 20 \mathrm{ppm}\left(\mathrm{T}_{4}\right)$ at fruit setting stage proved significantly effective in increasing initial fruit set, length of fruit, width of fruits, fruit volume, fruit weight, weight of fruit pulp and yield of fruit. The maximum fruit set, fruit retention and minimum fruit drop was observed with the application of $\mathrm{ZnSO}_{4} 0.6 \%\left(\mathrm{~T}_{9}\right)$.

\section{References}

Banker, G.J. and Prasad, R.M. (1990). Effect of gibberellic acid and NAA on fruit set and quality of fruit in ber cv. Gola. Prog. Hort., vol. 22(1-4): 60-62.

Bonner, J. (1950). Plant Biochemistry. Academic Press, New York.

Ebeed, S., El-Gazzar, A. and Bedier, R. (2001). Effect of foliar application of some micronutrients and growth regulators on fruit drop, yield, fruit quality and leaf mineral content of mango cv. Mesk. Annals of Agricultural Science Moshtohor, vol. 39: 1279-1296.

Kale, V.S., Kale, P.B. and Adpawar, R.W. (1999). Effect of plant growth regulators on fruit yield and quality of ber cv. Umran (Zizyphus mauritiana Lamk.). Annals of Pl. Physiol., vol. 13(1): 69-72.

Katiyar, P.N., Singh, J.P. and Singh, P.C. (2009). Foliar spray of growth regulators on fruiting, quality and yield in guava cv. Chittidar. International Journal of Agriculture Sciences, vol. 5(1): 173-174.

Kumar, J., Kumar, R., Rai, R. and Mishra, D.S. (2015). Effect of nutrients and plant growth regulators on physicochemical parameters and yield of guava (Psidium guajava L.) cv. Pant Prabhat. The Bioscan, vol. 10(2): 495-498. 
Omar, A.E., Al-Obeed, R.S., Al-Saif, A.M. and Soliman, S. (2015). The impact of foliar application of urea, zinc and Canada humex on yield and fruit properties of jujube cv. Puyin under Saudi Arabia conditions. The Journal of Agri. and Natural Resources Sci.,vol. 2(3): 524-529.

Painkara, P., Singh, R.K. and Prabhakar, H.K. (2012). Effect of growth regulators on fruit drop and physico-chemical composition of mango cv. Langra. Flora and Fauna (Jhansi), vol. 18(2): 213-216.

Pandey, A., Tripathi, V.K.; Pandey, M., Mishra, A.N. and Kumar, D. (2011). Influence of NAA, $\mathrm{GA}_{3}$ and zinc sulphate on fruit drop, growth, yield and quality of ber cv. Banarasi Karaka. Proceedings of the International Symposium on Minor Fruits and Medicinal Plants for Health and Ecological Security (ISMF \& MP), West Bengal, India, 19-22 December, 2011, pp. 184-187.

Pandey, V. (1999). Effect of NAA and $\mathrm{GA}_{3}$ spray on fruit retention, growth, yield and quality of ber (Zizyphus mauritiana Lamk.) cv. Banarasi Karaka. Orissa Journal of Horticulture, vol. 27: 69-73.

Rokaya, P.R., Baral, D.R., Gautam, D.M., Shrestha, A.K. and Paudyal, K.P. (2016). Effect of pre-harvest application of gibberellic acid on fruit quality and shelf life of mandarin. American $J$. of Plant Sci., vol.7(7): 1098-1105.

Sharma, J., Gupta, R.B., Panwar, R.D., Surender Singh and Bhatia, S.K. (2009). Yield and yield attributes of ber as influenced by soil application of phosphorus and zinc. Haryana Journal of Horticultural Sciences, vol. 38(3/4):181-183.

Singh, K., Randhawa, J.S. and Singh, K. (2001). Effect of growth regulators and fungicides on fruit drop, yield and quality of fruit in ber cv. Umran. J. Res. PAU, vol. 38(3-4): 181-185.

Singh, P.C., Gangwar, S.R., and Singh, V.K. (2012). Effect of micro-nutrients spray on fruit drop, fruit quality and yield of aonla cv. Banarasi. Hort. flora Research Spectrum, vol. 1(1): 73-76.

Van Overbeek, J. (1959). Auxins. Bot. Rev., 25: 269-350.

Wangbin, I., Wang, Y., Yue-hua, Z., Liu, J. and Xulin (2008). Effect of molybednum foliar sprays on fruiting, yield and fruit quality of Jujube. Proceedings of 1st International Jujube Symposium, pp. 55-56. Agricultural University of Hebei, Baoding, China.

Ying-yue, L., Jiu-ru, X. and Qing-hua, M. (2010). Trial on fruit setting promotion of different cultivars of Zizyphus mauritiana in greenhouse. Northern Horticulture, vol. 1: 628-665.

\section{How to cite this article:}

Poornima Devi, R.K.S. Gautam, Jyoti Singh, Sunil Kumar Maurya and Aneeta Chaudhary. 2019. Effect of Foliar Application of NAA, GA 3 and Zinc Sulphate on Fruit Drop, Growth and Yield of Ber (Zizyphus mauritiana Lamk.) c.v. Banarasi Karaka. Int.J.Curr.Microbiol.App.Sci. 8(01): 1679-1683. doi: https://doi.org/10.20546/ijcmas.2019.801.177 